\section{In Vivo Study of the Action of a Topical Anti-Inflammatory Drug In Rat Teeth Submitted To Dental Bleaching}

Francine Benetti ${ }^{1}$, André Luiz Fraga Briso², Luciana Louzada Ferreira' ${ }^{1}$, Marina Carminatti', Larissa Álamo', Edilson Ervolino³, Eloi Dezan-Júnior', Luciano Tavares Angelo Cintra ${ }^{1}$

Bleaching gel containing hydrogen peroxide $\left(\mathrm{H}_{2} \mathrm{O}_{2}\right)$ cause damages in pulp tissue. This study investigated the action of a topical anti-inflammatory, the Otosporin ${ }^{\circledR}$, in rats' bleached teeth with the null hypothesis of which the Otosporin ${ }^{\circledR}$ is no able to minimize the pulp inflammation that bleaching gel generates. The rat's molars were divided into groups: BLE: bleached ( $35 \% \mathrm{H}_{2} \mathrm{O}_{2}$ concentration /single application of $\left.30 \mathrm{~min}\right) ; \mathrm{BLE}-\mathrm{O}$ : bleached followed by Otosporin ${ }^{\circledR}(10 \mathrm{~min})$; and control: placebo gel. In the second day after dental bleaching, the rats were killed, and the jaws were processed for hematoxylineosin and immunohistochemistry analysis for tumor necrosis factor alpha (TNF- $\alpha$ ), interleukin (IL)-6 and IL-17. The data collected were subjected to Kruskal-Wallis and Dunn statistical tests with at a $5 \%$ level of significance $(p<0.05)$. The BLE group had moderate to strong inflammation in the occlusal third of the coronary pulp, with necrotic areas; and BLE- 0 , mild inflammation $(p<0.05)$. There was a significant difference in the occlusal and middle thirds of the coronary pulp between the BLE with BLE- 0 and control groups $(p<0.05)$. There was no difference in the cervical third ( $p>0.05)$. The BLE group had a high immunoexpression of TNF- $\alpha$ than BLE-O and control groups $(p<0.05)$, with moderate and mild immunoexpression, respectively. Regarding IL-6 and IL-17, the BLE group had higher immunoexpression than control $(p<0.05)$; the BLE-O was similar to the control $(p>0.05)$. The topical anti-inflammatory 0tosporin ${ }^{\circledR}$ can reduce pulp inflammation after dental bleaching in the rat teeth.
'Endodontics, Araçatuba Dental School, UNESP - Universidade Estadual Paulista, Araçatuba, SP, Brazil ${ }^{2}$ Restorative Dentistry, Araçatuba Dental School, UNESP - Universidade Estadual Paulista, Araçatuba, SP, Brazil ${ }^{3}$ Basic Science, Araçatuba Dental School, UNESP - Universidade Estadual Paulista, Araçatuba, SP, Brazil

Correspondence: Dr. Luciano Tavares Angelo Cintra, Rua José Bonifácio, 1193, Vila Mendonça, 16015-050 Araçatuba, SP, Brasil. Tel: +55-18-3636-2867. e-mail: luciano.cintra@unesp.br

Key Words: Anti-inflammatory agent, dental pulp, hydrogen peroxide, tooth bleaching.

\section{Introduction}

Dental bleaching is one of the most commonly used procedures in routine dental clinic when patients wish to whiten their teeth. However, studies have indicated that dental tissues undergo changes after performing this procedure $(1,2)$. Damage arises from the oxidation reaction that occurs between the reactive oxygen species (ROS) released by hydrogen peroxide $\left(\mathrm{H}_{2} \mathrm{O}_{2}\right)$ contained in bleaching gel with the organic and inorganic structures of tissues $(1,3)$.

With regard to dental pulp, it is well known that the ROS causes inflammatory events of various degrees in this tissue $(4-6)$ that are often considered irreversible $(4,5)$. The inflammation generated to the pulp tissue is related to the tooth sensitivity reported by most patients after dental bleaching (7).

Our previous studies showed the presence of chronic inflammatory infiltrate in the pulp after the bleaching procedure (6,8-10), which was greater with a higher concentration of bleaching gel (9-11), product application time (8), or number of sessions (5). Inflammation after dental bleaching is also reported in studies in cell culture (12) and humans' teeth (4).
Perhaps the most significant challenge of dental bleaching is to obtain a satisfactory result of brightening without promoting tooth sensitivity. Oral anti-inflammatory administration minutes before dental bleaching showed satisfactory effects in reducing tooth sensitivity immediately but not one-hour post-bleaching $(13,14)$. A meta-analysis showed that, in fact, there are several studies that evaluated the preemptive use of anti-inflammatories on tooth sensitivity caused by in-office bleaching but found insufficient evidence about the use of these to prevent tooth sensitivity caused by bleaching (15). Most likely, the drugs were unable to act on the inflammation caused to the pulpal tissue.

A recently published trial evaluated the prior topic use of dipyrone and also did not found any reduction on tooth sensitivity caused by in-office bleaching (16). However, Otosporin ${ }^{\circledR}$ is a drug with anti-inflammatory action differentiated by its strong penetrating power into tissue, which guarantees it to be better and fast acting (17). This medication consists of a combination of antibiotics polymyxin B sulfate and neomycin sulfate and hydrocortisone, which acts as an anti-inflammatory, immunosuppressant and vasoconstrictor (18) and is used 
in various endodontic procedures (19). Thus, the topical use of this drug could minimize the damage caused by dental bleaching.

In the study of Rezende et al. (16), the topical use of dipyrone was before of the bleaching session and is possible that the use of the topical anti-inflammatory after the bleaching session will have a better result, which has not yet been evaluated. Knowledge of the mechanism of action of Otosporin ${ }^{\circledR}$ over the pulp tissue of bleached teeth is important, especially the modulation of the inflammatory process. While the most of studies evaluated the preemptive oral administration of anti-inflammatory drugs (15), the present study aimed to evaluate the topic application of an anti-inflammatory after the bleaching.

The study of pro-inflammatory cytokines may be the key to a better understanding of how this relationship is established. We observed earlier that dental bleaching is capable of promoting an increase of the interleukin (IL)$6, \mathrm{IL}-17$ and tumor necrosis factor (TNF)- $\alpha$ in the dental pulp tissue $(6,10)$.

The objective of this study was to investigate the anti-inflammatory potential of Otosporin ${ }^{\circledR}$ by histological analysis and immunoexpression of pro-inflammatory cytokines TNF- $\alpha$, IL-6 and IL-17 in the pulp tissue of Wistar rats after dental bleaching. Null hypothesis: Otosporin ${ }^{\circledR}$ is not able to reduce the inflammation in the pulp tissue when applied after dental bleaching.

\section{Material and Methods}

\section{Bleaching and Anti-Inflammatory Protocols}

The hemimaxilla containing the molars of the right side of each rat were randomly divided into groups as follows $(n=10)$ : the BLE group received 35\% $\mathrm{H}_{2} \mathrm{O}_{2}$ (Whiteness HP Maxx; FGM Dental Products, Joinville, SC, Brazil); and the BLE-O group received $35 \% \mathrm{H}_{2} \mathrm{O}_{2}$ followed by Otosporin ${ }^{\circledR}$ (Farmoquímica S/A, Rio de Janeiro, RJ, Brazil). The hemimaxilla with the molars of the left side were the control group and received placebo gel. The rats were anesthetized by intramuscular injections of ketamine (80 $\mathrm{mg} / \mathrm{kg}$, Ketamina Agener 10\%, União Química Farmacêutica Nacional S/A, Embu-Guaçu, SP, Brazil) and xylazine (10 mg/ kg, Xilazin, Syntec do Brazil LTDA, Cotia, SP, Brazil). With the aid of a syringe of $1.0 \mathrm{~mL}, 0.01 \mathrm{~mL}$ of $\mathrm{H}_{2} \mathrm{O}_{2}$ gel was applied to the right upper 3 molars of bleached groups for a single application of $30 \mathrm{~min}$. Then, the molars were cleaned with cotton pellets and washed thoroughly with water. The BLE-0 group received a 10-min application of $0.01 \mathrm{~mL}$ of Otosporin ${ }^{\circledR}$, with the aid of a syringe of $1.0 \mathrm{~mL}$, after the bleaching session. The control group received 30 minutes of placebo gel (the vehicle for the bleaching gel) composed of the thickener with the addition of distilled water in the proportion of 3:1.

\section{Histology and Immunohistochemical Analysis}

Two days after the bleaching and anti-inflammatory session (8) the animals were euthanized with an overdose of Thiopental anesthetic $(240 \mathrm{mg} / \mathrm{kg}$, Thipentax, Cristália - Produtos Químicos Farmacêuticos Ltda, Itapira, SP, Brazil). The hemimaxilla were separated, dissected and fixed in a solution of $4 \%$ buffered formaldehyde for $24 \mathrm{~h}$. The specimens were decalcified in a 10\% ethylenediaminetetraacetic acid solution for three months and then dehydrated, clarified and embedded in paraffin.

The serial histological sections of each specimen were selected from the point where the mesial root of the first molar was seen at its full longitudinal extension. Five-micron sections were performed in the vestibularlingual plane. The blades with sections were stained with hematoxylin-eosin or submitted to immunohistochemistry.

Immunohistochemistry was performed using an indirect imunoperoxidase technique $(6,10)$ for TNF- $\alpha(1: 100$, goat anti-TNF- $\alpha$, SC 1350; Santa Cruz Biotechnology, Santa Cruz, CA, USA), IL-6 (1:100, rabbit anti-IL-6, SC 1265; Santa Cruz Biotechnology) and IL-17 (1:100, rabbit anti-IL-17, SC 7927; Santa Cruz Biotechnology). The histological sections were deparaffinized in xylene and hydrated in a decreasing ethanol series. Antigen retrieval was achieved by immersing the histological slides in citrate buffer solution (Antigen Retrieval Buffer; Spring Bioscience, Pleasanton, CA, USA) in a pressurized chamber (Decloaking Chamber; Biocare Medical, Concord, CA, USA) at $95^{\circ} \mathrm{C}$ for $10 \mathrm{~min}$. The slides were rinsed with phosphate-buffered saline at the end of each stage of the immunohistochemical reaction. The histological sections were immersed in $3 \% \mathrm{H}_{2} \mathrm{O}_{2}$ solution for $1 \mathrm{~h}$ and $20 \mathrm{~min}$ and in $1 \%$ bovine serum albumin for $12 \mathrm{~h}$ to block the endogenous peroxidase activity and nonspecific sites, respectively. The histological slides were divided and incubated with one of the primary antibodies, that were diluted (Antibody Diluent with Background Reducing Components; Dako Laboratories, Carpinteria, CA, USA) and placed in a moist chamber for $24 \mathrm{~h}$. The histological sections were incubated with a biotinylated secondary antibody for $1 \mathrm{~h}$ and $30 \mathrm{~min}$ and were subsequently treated with streptavidin-horseradish peroxidase conjugate for $1 \mathrm{~h}$ and 30 min (Universal Dako Labelled Streptavidin-Biotin kit; Dako Laboratories). The slides were rinsed with phosphatebuffered saline, and the reaction was developed using the chromogen 3,3'-diaminobenzidine tetrahydrochloride (DAB Chromogen kit; Dako Laboratories) and was counterstained with Harris's hematoxylin. The negative controls consisted of specimens submitted to the procedures previously mentioned but without the primary antibodies.

Histological and immunohistochemical analysis were performed by a single calibrated operator in a blinded manner under light microscopy (400×, DM 4000 B; Leica, 
Wetzlar, Germany). For the histological analysis, the pulp chamber was divided into thirds (occlusal, middle and cervical) (5), and inflammation was scored considering the intensity and cell distribution in accordance with the approximate average number of inflammatory cells present in each third of the same specimen (Table 1) (5). For immunohistochemical analysis, pre-established scores were applied to the immunoexpression (Table 1) $(6,10)$ that was considered in the cells and extracellular matrix. The analysis was performed considering the full extent of the pulp chamber in the histological section.

\section{Statistical Analysis}

The data collected were subjected to Kruskal-Wallis and Dunn statistical tests with Sigma Plot software (San Jose, $C A)$ at a $5 \%$ level of significance.

\section{Results}

\section{Histological Analysis}

The control group had tissue organization in the full extent of the pulp chamber and an absence of inflammation. We observed that the pulp tissue of bleached groups had histological features including tissue disorganization and inflammatory infiltrate. Statistically analyzing the inflammatory infiltrate and the presence of necrosis, these features were highest in the BLE group, which had areas of

Table 1. Scores attributed to the intensity of inflammatory cell infiltration and immunoexpression to TNF- $\alpha$, IL- 6 and IL-17

\begin{tabular}{|c|c|}
\hline Score & Scores to intensity of inflammatory cell infiltration \\
\hline 1 & Inflammatory cells absent or negligible in number \\
\hline 2 & Mild inflammatory infiltrate ( $<25$ cells per field) \\
\hline 3 & $\begin{array}{l}\text { Moderate inflammatory infiltrate (between } \\
25 \text { and } 125 \text { cells per field) }\end{array}$ \\
\hline 4 & $\begin{array}{l}\text { Severe inflammatory infiltrate ( }>125 \\
\text { cells per field) or necrosis }\end{array}$ \\
\hline Score & Scores to immunoexpression \\
\hline 0 & $\begin{array}{l}\text { Immunolabeling missing (absence of } \\
\text { labeling in extracellular matrix and complete } \\
\text { absence of immunoreactive cells) }\end{array}$ \\
\hline 1 & $\begin{array}{l}\text { Low immunoexpression (weak labeling of } \\
\text { the extracellular matrix and approximately } \\
\text { one quarter of the immunoreactive cells) }\end{array}$ \\
\hline 2 & $\begin{array}{l}\text { Moderate immunoexpression (moderate labeling } \\
\text { of the extracellular matrix and approximately } \\
\text { one half of the immunoreactive cells) }\end{array}$ \\
\hline 3 & $\begin{array}{l}\text { Strong immunoexpression(strong labeling of } \\
\text { the extracellular matrix and approximately } \\
\text { three quarters of the immunoreactive cells) }\end{array}$ \\
\hline 4 & $\begin{array}{l}\text { Very severe immunoexpression (extremely } \\
\text { strong labeling of the extracellular matrix and } \\
\text { approximately all immunoreactive cells) }\end{array}$ \\
\hline
\end{tabular}

necrosis in most specimens, especially in the occlusal third of the coronal pulp. Necrosis was not observed in the BLE-O group. The scores attributed to the inflammatory infiltrate in the pulp tissue of each group can be visualized in Table 2.

Table 2. Scores observed for the inflammatory cell response and for immunoexpression according to the groups

\begin{tabular}{|c|c|c|c|c|c|}
\hline \multirow{2}{*}{ Analysis } & \multirow{2}{*}{ Scores } & \multicolumn{3}{|c|}{ Groups } & \multirow{2}{*}{$\mathrm{p}$} \\
\hline & & Cont & BLE & BLE-0 & \\
\hline \multirow{5}{*}{ HE (occlusal) } & 1 & $10 / 10$ & $0 / 10$ & $4 / 10$ & \multirow{5}{*}{$<0.001$} \\
\hline & 2 & $0 / 10$ & $0 / 10$ & $5 / 10$ & \\
\hline & 3 & $0 / 10$ & $5 / 10$ & $1 / 10$ & \\
\hline & 4 & $0 / 10$ & $5 / 10$ & $0 / 10$ & \\
\hline & Median* & $1^{\mathrm{a}}$ & $4^{\mathrm{b}}$ & $2^{\mathrm{a}}$ & \\
\hline \multirow{5}{*}{ HE (middle) } & 1 & $10 / 10$ & $0 / 10$ & $5 / 10$ & \multirow{5}{*}{$<0.001$} \\
\hline & 2 & $0 / 10$ & $4 / 10$ & $4 / 10$ & \\
\hline & 3 & $0 / 10$ & $5 / 10$ & $1 / 10$ & \\
\hline & 4 & $0 / 10$ & $1 / 10$ & $0 / 10$ & \\
\hline & Median* & $1^{\mathrm{a}}$ & $3^{\mathrm{b}}$ & $1^{\mathrm{a}}$ & \\
\hline \multirow{5}{*}{ HE (cervical) } & 1 & $10 / 10$ & $4 / 10$ & $7 / 10$ & \multirow{5}{*}{$<0.001$} \\
\hline & 2 & $0 / 10$ & $6 / 10$ & $3 / 10$ & \\
\hline & 3 & $0 / 10$ & $0 / 10$ & $0 / 10$ & \\
\hline & 4 & $0 / 10$ & $0 / 10$ & $0 / 10$ & \\
\hline & Median* & $1^{\mathrm{a}}$ & $2^{\mathrm{a}}$ & $1^{\mathrm{a}}$ & \\
\hline \multirow{6}{*}{ TNF- $\alpha$} & 0 & $0 / 10$ & $0 / 10$ & $0 / 10$ & \multirow{6}{*}{$<0.001$} \\
\hline & 1 & $9 / 10$ & $0 / 10$ & $1 / 10$ & \\
\hline & 2 & $1 / 10$ & $0 / 10$ & $9 / 10$ & \\
\hline & 3 & $0 / 10$ & $8 / 10$ & $0 / 10$ & \\
\hline & 4 & $0 / 10$ & $2 / 10$ & $0 / 10$ & \\
\hline & Median* & $1^{\mathrm{a}}$ & $3^{\mathrm{b}}$ & $2^{\mathrm{a}}$ & \\
\hline \multirow{6}{*}{ IL-6 } & 0 & $0 / 10$ & $0 / 10$ & $0 / 10$ & \multirow{6}{*}{0.009} \\
\hline & 1 & $10 / 10$ & $4 / 10$ & $4 / 10$ & \\
\hline & 2 & $0 / 10$ & $4 / 10$ & $6 / 10$ & \\
\hline & 3 & $0 / 10$ & $2 / 10$ & $0 / 10$ & \\
\hline & 4 & $0 / 10$ & $0 / 10$ & $0 / 10$ & \\
\hline & Median* & $1^{\mathrm{a}}$ & $2^{\mathrm{b}}$ & $2^{\mathrm{ab}}$ & \\
\hline \multirow{6}{*}{ IL-17 } & 0 & $0 / 10$ & $0 / 10$ & $0 / 10$ & \multirow{6}{*}{0.008} \\
\hline & 1 & $8 / 10$ & $2 / 10$ & $2 / 10$ & \\
\hline & 2 & $2 / 10$ & $6 / 10$ & $8 / 10$ & \\
\hline & 3 & $0 / 10$ & $2 / 10$ & $0 / 10$ & \\
\hline & 4 & $0 / 10$ & $0 / 10$ & $0 / 10$ & \\
\hline & Median* & $1^{\mathrm{a}}$ & $2^{\mathrm{b}}$ & $2^{\mathrm{ab}}$ & \\
\hline
\end{tabular}

Same letters in the rows indicate no statistically significant difference among the groups ( $p>0.05$ ). 


\section{Immunohistochemical Analysis}

All groups showed positive immunoexpression for TNF- $\alpha$, IL-17 and IL-6. The extracellular matrix showed positive expression in specimens of all of the groups, mainly in the occlusal and middle thirds of the coronary pulp of the bleached groups. Positive expression was also observed in the cytoplasm of cells. The aspects of immunohistochemistry are shown in Figure 1.

Most specimens in the control group showed a low immunoexpression for TNF- $\alpha$; in the BLE group, there was a strong immunoexpression in most specimens. The BLE-0 group displayed a moderate immunoexpression (Fig. 1, Table 2).

In the analysis of IL-6 and IL-17, a low immunoexpression was predominant in specimens in the control group; the BLE group showed some specimens with a strong immunoexpression. In the BLE-0 group, most specimens showed a moderate immunoexpression, and some specimens had low immunoexpression (Fig. 1, Table 2).

\section{Comparison Among the Groups}

The comparison between the scores attributed to the inflammatory infiltrate and immunoexpression of each $\vec{z}$ group is presented in Table 2. In the histological analysis, inflammation was significantly higher in the BLE group compared to the other groups in the occlusal and middle thirds of the coronary pulp $(p<0.05)$; there was no difference between groups in the cervical third ( $p>0.05)$. The BLE-0 group was similar to the control group in all thirds of the coronary pulp $(p>0.05)$.

In the immunohistochemical analysis, the BLE group had higher immunoexpression significance for TNF- $\alpha$ compared to the other groups $(p<0.05)$ and higher immunoexpression significance for IL-6 and IL-17 when compared to the control group $(p<0.05)$. The BLE-0 group was similar to the control group in the analysis of all inflammatory markers $(p>0.05)$.

\section{Discussion}

Our previous studies with rat molars $(5,6,8,9)$, and humans (4), as well as studies in vitro with cultured cells and an artificial pulp chamber (12), showed that bleaching gel damages pulp tissue. Thus, we sought solutions through anti-inflammatory drugs to minimize the damage. This in vivo study analyzed the anti-inflammatory potential of Otosporin ${ }^{\circledR}$ on the pulp tissue of rat teeth after dental bleaching and revealed that this drug was capable of minimizing the damage caused to the pulp tissue by

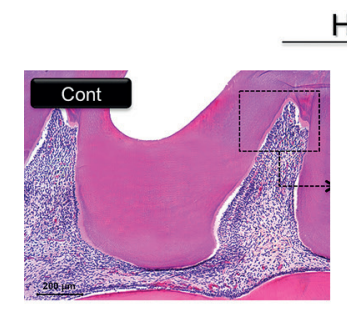

HE
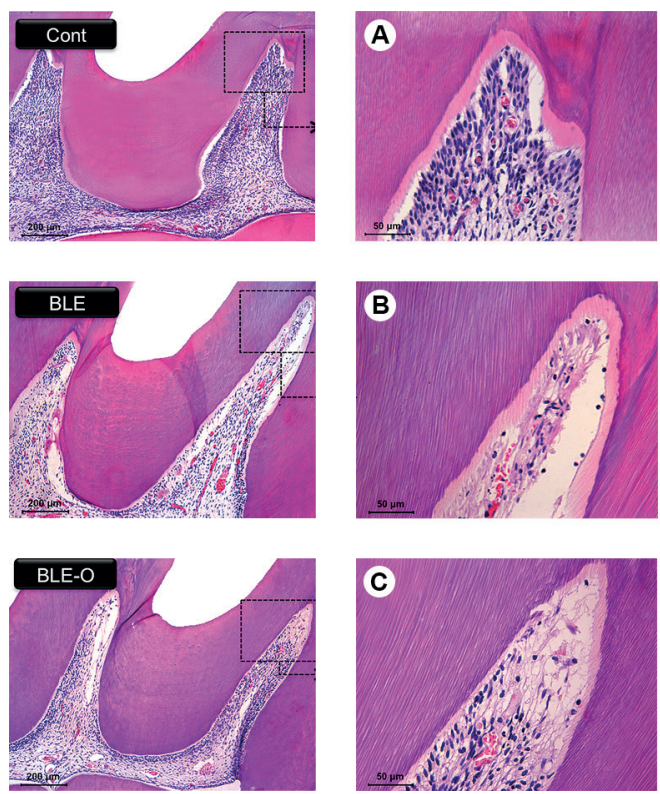
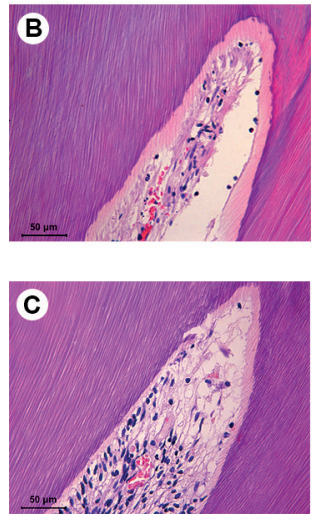

TNF- $\alpha$
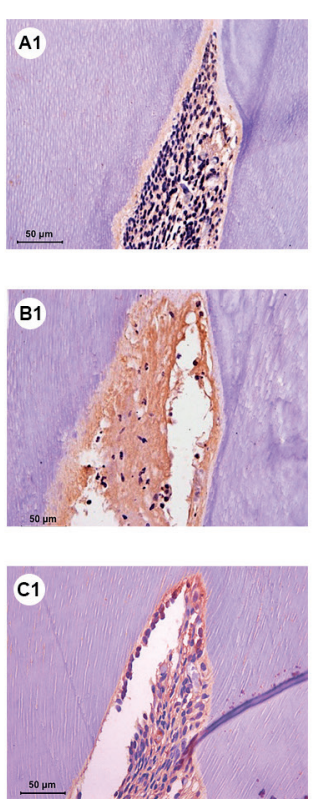

IL-6
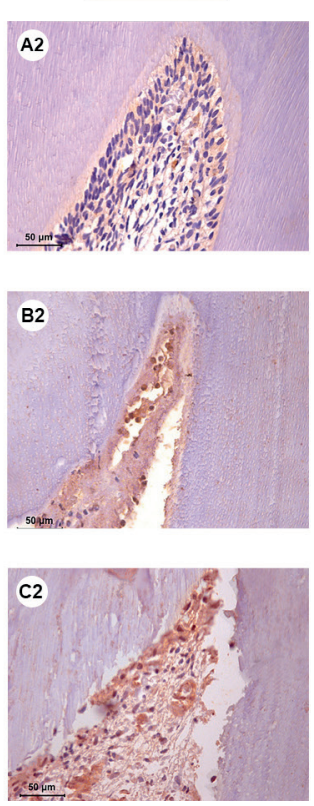
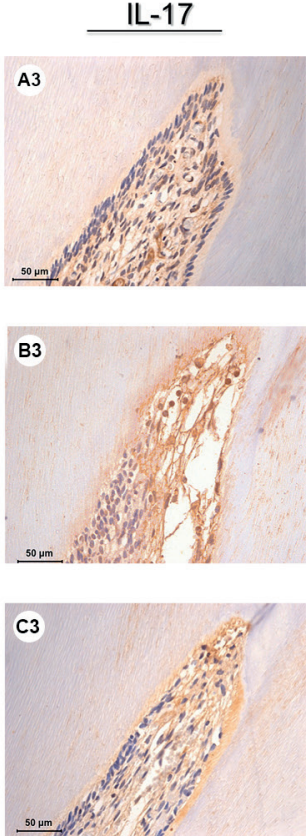

Figure 1. Representative photomicrographs of inflammation response and immunohistochemical labeling of the control and bleached groups. Cont: photomicrograph of control group showing organized tissue; (a) pulp horns area with an absence of inflammation and organized cell layers; (a1-a3) photomicrographs evidencing low immunoexpression for (a1) TNF- $\alpha$, (a2) IL-6 and (a3) IL-17. BLE: photomicrograph of the BLE group showing the necrosis area; (b) pulp horns area with evidenced necrosis; (b1-b3) photomicrographs evidencing strong immunoexpression for (b1) TNF- $\alpha$ and moderate immunoexpression for (b2) IL-6 and (b3) IL-17. BLE-0: photomicrograph of the BLE-0 group showing mild inflammatory infiltrate in the region of the occlusal third; (c) pulp horns area with presence of inflammatory cells; (c1-c3) photomicrographs evidencing moderate immunoexpression for (c1) TNF- $\alpha$, (c2) IL-6 and (c3) IL-17. [HE staining: 100x, 400x; immunohistochemical labeling for TNF- $\alpha$, IL-6 and IL-17: 400x]. 
bleaching agents, which rejects our initial hypothesis.

Other oral anti-inflammatory drugs have been tested, but the results were not satisfactory (13). These results may indicate that oral anti-inflammatory drugs may not influence the response of the pulp tissue. In this way, a previous study used a non-steroidal anti-inflammatory topically in a failed attempt to reduce post-operative bleaching sensitivity (16). However the medication was used before bleaching gel. Our results were different, which may be due not only to the properties of the medication used in this study, but mainly by using it topically after the application of the bleaching gel.

Otosporin ${ }^{\circledR}$ is known as a medicine with high penetration capacity due your vehicle (17). The composition of Otosporin ${ }^{\circledR}$ consists of neomycin sulfate, polymyxin B sulfate and hydrocortisone. The corticosteroid action of Otosporin ${ }^{\circledR}$ is what highlights this drug to be used as an anti-inflammatory agent to inflamed pulpal tissue, and its use has been reported in previous studies $(17,19)$. It was shown that it has the capacity to penetrate into dentin and reduce the dental sensitivity after the preparation of deep cavities. With regard to enamel, microcracks present in its superficies (1) also could favor the penetration of Otosporin ${ }^{\circledR}$ through this tissue, reaching the dentin-pulp complex. This could increase after the use of $\mathrm{H}_{2} \mathrm{O}_{2}$, which increases the porosity of enamel (1).

It is reported that most patients who undergo the bleaching procedure have postoperative sensitivity $(7,13)$. A previous study showed that the risk of dental sensitivity is higher in office bleaching, with $62.9 \%$ of patients reporting sensitivity when compared to the home bleaching group, where the risk of dental sensitivity was $51 \%$ (7). Studies suggest that tooth sensitivity is closely related to inflammation generated by bleaching agents to pulp (7). This is due to the diffusion of $\mathrm{H}_{2} \mathrm{O}_{2}$ by enamel and dentin (11), which can be seen, in the dentin-pulp complex (5) causing inflammation of the pulp $(2,12)$. Pain after bleaching treatments can also affect healthy teeth, as opposed to common tenderness, where pain occurs in exposed dentin (7).

Otosporin ${ }^{\circledR}$ reduced the inflammation the bleaching agent caused and thus possibly can minimize patients' postoperative sensitivity. The immunohistochemical analysis also indicates some influence of Otosporin ${ }^{\circledR}$ in the inflammatory process of pulp tissue after dental bleaching. Histologically, the control group showed intact pulp tissue with layers of dentin without change and in continuity with the layer of odontoblasts. This group showed low immunoexpression for TNF- $\alpha$, IL- 6 and IL-17. Other studies also revealed that levels of cytokines are expressed in normal healthy teeth (20). After dental bleaching, the levels of these cytokines increased. However, the BLE-O group presented lower TNF- $\alpha$ immunoexpression compared to the BLE group, and the immunoexpression for IL-6 and IL-17 was similar to that found in the control group, which did not occur with the BLE group.

TNF- $\alpha$ and IL- 6 regulate the attraction of inflammatory cells and were found in odontoblasts and fibroblasts after pulpal injury caused by dental materials $(10,12)$. They were also present after $\mathrm{H}_{2} \mathrm{O}_{2}$ application to cell cultures (12). TNF- $\alpha$ is a central mediator in initiating the cascade of inflammation, including the induction of cytokine production, as the IL-6 (21). TNF- $\alpha$ also causes dilation and increased permeability of blood vessels (21). High levels of this cytokine were found in inflamed pulp tissue $(10,20)$, as observed in this study. Furthermore, pulps with symptomatic irreversible pulpitis showed higher levels of TNF- $\alpha$ compared with pulps with asymptomatic irreversible pulpitis and normal pulps (20).

IL-6 acts as an important mediator of inflammation, and similar to TNF- $\alpha$, it also induces vascular permeability, resulting in inflammatory edema (21). As a consequence, intra-pulp pressure may be increased, leading to clinical symptoms (21). In this study, the levels of TNF- $\alpha$ and IL-6 were increased after dental bleaching. Thus, these cytokines can be correlated with symptoms in bleached teeth, characterized as dental sensitivity.

It is essential to regulate increases in intra-pulp pressure caused by these mediators to avoid greater damage of tissue. Otosporin ${ }^{\circledR}$, through corticosteroid action, can act to minimize the dilation of blood vessels and therefore the inflammatory process, a fact demonstrated by decreased labeling of inflammatory mediators. In addition, as these mediators are related symptoms, they would also be minimized by the action of Otosporin ${ }^{\circledR}$. Furthermore, depending on the concentration of these mediators in the pulp tissue, degenerative effects may occur, such as the release of proteolytic enzymes capable of damaging the tissue (22). It is therefore important that these markers are regulated in the inflammatory process.

Other studies suggest that ROS causes the release of chemical mediators that may sensitize pulp nociceptors (23). Still, the ROS can directly increase the expression of substance $\mathrm{P}(\mathrm{SP})$, a nociceptive neurotransmitter responsible for the modulation and sensation of pain (22). SP was shown to be capable of increasing the $T$ helper 17-cell response characterized as a preferential producer of proinflammatory IL-17 cytokine (24). In the present study, IL-17 was increased in the presence of the bleaching gel, and Otosporin ${ }^{\circledR}$ showed potential to reduce levels of this cytokine. As SP was elevated in pulp tissue after bleaching procedure (23), we can speculate that Otosporin ${ }^{\circledR}$ may also act on SP, minimizing IL-17 levels. Studies to investigate this possible action are good direction for future research. 
IL-17 is well known in periapical lesions and in bone-resorption processes, but its role in pulpitis is not well understood (10). It is known that IL-17 stimulates the production of the other cytokines in human dental pulp fibroblasts and T-cell proliferation (10), in addition to being related to increases in neutrophil. Studies also show that SP-induced IL-17 in cell culture may increase the production of IL-6 (24). Thus, the reduction of IL-17 may have contributed to the reduction of IL-6 levels in the present study.

In general, the presence of cytokines in the intracellular space leads to increase of phagocytosis and the release of toxic agents to eliminate the aggressor (20). This can have a beneficial or deleterious effect on tissue, depending on the active time (21). The use of anti-inflammatory agents is important to minimize aggression, prevent the progression of inflammation to necrosis and help the pulp tissue repair.

However, it has been previously reported the role of sensory nerves in responses induced by oxidizing agents (25). Nociceptive afferent fibers express many receptors, among them the transient receptor potential ankyrin 1 (TRPA1), which has been found to be an important mediator of $\mathrm{H}_{2} \mathrm{O}_{2}$-induced pain and its sub-products (25). $\vec{\sigma}$ Thus, it is important to note that pain reported by patients undergoing bleaching procedures is largely related to the activation of TRAP1, and that reduction of inflammation may not necessarily indicate a significant clinical reduction of tooth sensitivity (25). However, it has been found that TRPA1 is involved in the detection of toxic compounds, as sub-products of the oxidation of various pathological conditions of chronic inflammation (25). That is, damage to the pulp tissue is observed after bleaching, which generates cellular peroxidation, resulting in products that would further sensitize TRPA1. Thus, inflammation and tooth sensitivity are closely linked, but it is necessary to check in the future if Otosporin ${ }^{\circledR}$ has an effect on the reduction of TRPA1 sensitization, reinforcing that this drug can minimize post-bleaching sensitivity.

Although it has been performed on rat teeth, this study provides relevant information on the pathogenesis of pulp inflammation by the bleaching, which was controlled by the use of Otosporin ${ }^{\circledR}$ as anti-inflammatory. This because rat molars have the same anatomical, histological, biological and physiological characteristics of human teeth, besides the same proportion of enamel and dentin (8). When evaluating the influence of the bleaching on the pulp, Cintra et al. (8), could verify the similarity of their results with the findings of the study by Costa et al. (4), who performed a similar analysis, but in human incisors. Because of these similarities, the authors suggest that studies in molars of Wistar rats can be targeted and improved to predict results of procedures performed on human teeth. However, clinical studies involving pain-related markers may be important to verify the possible reduction of tooth sensitivity through the use of Otosporin ${ }^{\circledR}$ after bleaching.

This study indicates that dental bleaching is capable of causing damage to the pulp tissue of rat molars, and this damage can be minimized by use of Otosporin ${ }^{\circledR}$ after the bleaching procedure.

\section{Resumo}

0 gel clareador à base de peróxido de hidrogênio $\left(\mathrm{H}_{2} \mathrm{O}_{2}\right)$ causa danos ao tecido pulpar. Este estudo investigou a ação de um anti-inflamatório tópico, o Otosporin ${ }^{\circledR}$, nos dentes de ratos clareados com a hipótese nula de que o Otosporin ${ }^{\circledR}$ não é capaz de minimizar a inflamação da polpa gerada pelo gel clareador. Os molares dos ratos foram divididos em grupos: $\mathrm{CIA}$ : clareado $\left(\mathrm{H}_{2} \mathrm{O}_{2}\right.$ a 35\% / aplicação única de 30 min); CLA-0: clareado seguido do Otosporin ${ }^{\circledR}(10 \mathrm{~min})$; e controle: gel placebo. No segundo dia após a clareação dentária, os ratos foram mortos e suas maxilas foram processadas para análise de hematoxilina-eosina e imunohistoquímica para o fator de necrose tumoral alfa (TNF- $\alpha$ ), interleucina (IL)-6 e IL-17. Os dados coletados foram submetidos aos testes estatisticos de KruskalWallis e Dunn com um nível de significância de 5\% $(p<0,05)$. 0 grupo CLA apresentou inflamação moderada à severa no terço oclusal da polpa coronária, com áreas necróticas; e CLA-0, inflamação leve $(p<0,05)$. Houve diferença significativa nos terços oclusal e médio da polpa coronária entre o grupo CLA com os grupos CLA-0 e controle $(p<0,05)$. Não houve diferença no terço cervical $(p>0,05)$. 0 grupo CLA apresentou maior imunoexpressão para TNF- $\alpha$ comparado aos grupos CLA-0 e controle $(p<0,05)$, com imunoexpressão moderada e leve, respectivamente. Em relação a IL-6 e IL-17, o grupo CLA apresentou maior imunoexpressão comparado ao controle $(p<0,05)$; o CLA-0 foi semelhante ao controle $(p>0,05) .0$ anti-inflamatório tópico Otosporin ${ }^{\circledR}$ pode reduzir a inflamação pulpar após clareação em dentes de ratos.

\section{Acknowledgements}

This study was supported by a grant (2014/09736-2 and 2015/10825-2) from the São Paulo Research Foundation (FAPESP), São Paulo, SP, Brazil and National Council for Scientific and Technological Development (CNPq) (455943/2014-1 and 305969/2015-3).

\section{References}

1. Markovic L, Jordan RA, Lakota N, Gaengler P. Micromorphology of enamel surface after vital tooth bleaching. J Endod 2007;33:607-610.

2. Benetti $F$, Lemos CAA, de Oliveira Gallinari M, Terayama AM1, Briso ALF3, de Castilho Jacinto $R$, et al. Influence of different types of light on the response of the pulp tissue in dental bleaching: a systematic review. Clin Oral Investig 2018;22:1825-1837.

3. Cintra LTA, Ferreira LL, Benetti F, Gastélum AA, Gomes-Filho JE, Ervolino $E_{1}$ et al. The effect of dental bleaching on pulpal tissue response in a diabetic animal model. Int Endod J 2017;50:790-798.

4. Costa CA, Riehl H, Kina JF, Sacono NT, Hebling J. Human pulp responses to in-office tooth bleaching. Oral Surg Oral Med Oral Pathol Oral Radiol Endod 2010;109:e59-e64.

5. Cintra LT, Benetti F, da Silva Facundo AC, Ferreira LL, Gomes-Filho JE,

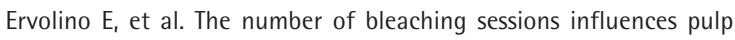
tissue damage in rat teeth. J Endod 2013;39:1576-80.

6. Ferreira LL, Gomes-Filho JE, Benetti F, Carminatti M, Ervolino E, Briso $A L F$, et al. The effect of dental bleaching on pulpal tissue response in a diabetic animal model: Immunoregulatory cytokines study. Int Endod J 2017;51:347-356

7. Rezende $M$, Loguercio $A D$, Kossatz $S$, Reis A. Predictive factors on the efficacy and risk/intensity of tooth sensitivity of dental bleaching: A multi regression and logistic analysis. J Dent 2016;45:1-6. 
8. Cintra LT, Benetti F, Ferreira LL, Rahal V, Ervolino E, Jacinto Rde C, et al. Evaluation of an experimental rat model for comparative studies of bleaching agents. J Appl Oral Sci 2016;24:95-104.

9. Benetti $F$, Gomes-Filho JE, Ferreira LL, Ervolino E, Briso ALF, SivieriAraújo $\mathrm{G}$, et al. Hydrogen peroxide induces cell proliferation and apoptosis in pulp of rats after dental bleaching in vivo: Effects of the dental bleaching in pulp. Arch Oral Biol 2017;81:103-109.

10. Benetti F, Gomes-Filho JE, Ferreira LL, Sivieri-Araújo G, Ervolino E, Briso $A L F$, et al. Concentration-dependent effect of bleaching agents on the immunolabelling of interleukin-6, interleukin-17 and CD5-positive cells in the dental pulp. Int Endod J 2018;51:789-799.

11. Cintra LT, Benetti F, Ferreira LL, Gomes-Filho JE, Ervolino E, Gallinari Mde 0 , et al. Penetration Capacity, Color Alteration and Biological Response of Two In-office Bleaching Protocols. Braz Dent J 2016;27:169-75.

12. Soares DG, Basso FG, Scheffel DS, Hebling J, de Souza Costa CA. Responses of human dental pulp cells after application of a lowconcentration bleaching gel to enamel. Arch Oral Biol 2015;9:1428-36.

13. Charakorn P, Cabanilla LL, Wagner WC, Foong WC, Shaheen J, Pregitzer $R$, et al. The effect of preoperative ibuprofen on tooth sensitivity caused by in-office bleaching. Oper Dent 2009;34:131-5.

14. Fernandes MT, Vaez SC, Lima CM, Nahsan FP, Loguércio AD, Faria-ESilva AL. Preemptive use of naproxen on tooth sensitivity caused by in-office bleaching: a triple-blind, crossover, randomized clinical trial. Oper Dent 2017;42:486-496.

15. Faria-E-Silva AL, Nahsan FP, Fernandes MT, Martins-Filho PR. Effect of preventive use of nonsteroidal anti-inflammatory drugs on sensitivity after dental bleaching: a systematic review and meta-analysis. J Am Dent Assoc 2015;146:87-93.

16. Rezende M, Chemin K, Vaez SC, Peixoto AC, Rabelo JF, Braga SSL, et al. Effect of topical application of dipyrone on dental sensitivity reduction after in-office dental bleaching: A randomized, triple-blind multicenter clinical trial. J Am Dent Assoc 2018;149:363-371.

17. Panzarini SR, Trevisan CL, Brandini DA, Poi WR, Sonoda CK, Luvizuto
$E R$, et al. Intracanal dressing and root canal filling materials in tooth replantation: a literature review. Dent Traumatol 2012;28:42-48

18. Smith RB, Moodie J. Comparative efficacy and tolerability of two antibacterial/anti-inflammatory formulations ('Otomize' spray and 'Otosporin' drops) in the treatment of otitis externa in general practice. Curr Med Res Opin 1990;11:661-667

19. Marinho AC, Polay AR, Gomes BP. Accuracy of turbidimetric limulus amebocyte lysate assay for the recovery of endotoxin interacted with commonly used antimicrobial agents of endodontic therapy. J Endod 2015;41:1653-659

20. Pezelj-Ribaric S, Anic I, Brekalo I, Miletic I, Hasan M, Simunovic-Soskic M. Detection of tumor necrosis factor alpha in normal and inflamed human dental pulps. Arch Med Res 2002;33:482-484.

21. Castell JV, Gómez-Lechón MJ, David M, Fabra R, Trullenque R, Heinrich $P C$. Acute-phase response of human hepatocytes: regulation of acutephase protein synthesis by interleukin-6. Hepatology 1990;12:11791186.

22. Goodis HE, Bowles WR, Hargreaves KM. Prostaglandin E2 enhances bradykinin-evoked iCGRP release in bovine dental pulp. J Dent Res 2000;79:1604-1607.

23. Caviedes-Bucheli J, Ariza-Garcia G, Restrepo-Méndez S, Ríos-Osorio N, Lombana N, Muñoz HR. The effect of tooth bleaching on substance P expression in human dental pulp. J Endod 2008;34:1462-1465.

24. Shimizu M, Yamaguchi M, Fujita S, Utsunomiya T, Yamamoto H, Kasai K. Interleukin-17/T-helper 17 cells in an atopic dermatitis mouse model aggravate orthodontic root resorption in dental pulp. Eur J Oral Sci 2013;121:101-110.

25. Markowitz K. Pretty painful: why does tooth bleaching hurt? Med Hypotheses. 2010;74:835-840.

Received March 6, 2018 Accepted July 13, 2018 